\section{Metabolic syndrome in the pediatric population: a short overview}

\author{
Natasa Marcun Varda, Alojz Gregoric \\ Department of Paediatrics, University \\ Medical Centre, Maribor, Slovenia
}

\section{Abstract}

The metabolic syndrome (MS) in adults is defined as a concurrence of obesity, disturbed glucose and insulin metabolism, hypertension and dyslipidemia, and is associated with increased morbidity and mortality from cardiovascular diseases and type 2 diabetes. Studies now indicate that many of its components are also present in children and adolescents. Moreover, the clustering of these risk factors has been documented in some children, who are at increased cardiovascular risk in adulthood. The MS is highly prevalent among overweight children and adolescents. Identifying these children is important for early prevention and treatment of different components of the syndrome. The first-line treatment comprises lifestyle modification consisting of diet and exercise. The most effective tool for prevention of the MS is to stop the development of childhood obesity. The first attempt at consensus-based pediatric diagnostic criteria was published in 2007 by the International Diabetes Federation. Nevertheless, national prevalence data, based on uniform pediatric definition, protocols for prevention, early recognition and effective treatment of pediatric MS are still needed.

The aim of this article is to provide a short overview of the diagnosis and treatment options of childhood MS, as well as to present the relationships between MS and its individual components.

\section{Introduction}

More than 20 years have passed since the first description of metabolic syndrome (MS) in adults. ${ }^{1}$ During this time, many expert groups have proposed definitions of MS, with some common characteristics and some differences. ${ }^{2-5}$ The purpose of these definitions has been to determine which patients are at increased cardiovascular (CV) risk. At present the view held is that in each adult patient with a single CV risk factor, all the other known risk factors have to be looked for and individually treated. ${ }^{6,7}$ On the other hand, in children, till now, only one consensus-based definition of pediatric MS has been published, ${ }^{8}$ although many studies have shown that MS and its components do appear in childhood. ${ }^{9}$ In fact, their prevalence is on the increase, ${ }^{10,11}$ mostly on account of obesity. ${ }^{12,13}$ Obesity and the closely linked insulin resistance are presumed to play a central role in the development of MS. ${ }^{14,15}$ Many studies have also shown that clustering of $\mathrm{CV}$ risk factors continues into adulthood ${ }^{16}$ and predicts the risk of future CV events and diabetes. $^{17,18}$ In numerous epidemiological studies, the negative influence of MS on CV morbidity and mortality and on type 2 diabetes has been documented..$^{19,20}$ On the other hand, lower CV risk and prevalence of MS have been established in children and adults with MS components in the lower normal range, independent of a positive family history of CV disease (clinical marker of genetic predisposition). ${ }^{21,22}$ This further indicates the important role of a healthy lifestyle in early childhood in the prevention of $\mathrm{CV}$ diseases.

In this review article we describe definitions of MS, discuss its pathophysiology, point out the management and treatment options, and present physiological mechanisms between MS and its constitutive elements.

\section{Definition of metabolic syndrome}

MS was first described by Reaven. ${ }^{1}$ In subsequent years different names have been used, namely, dysmetabolic syndrome, syndrome X, cardiometabolic syndrome, deadly quartet and insulin resistance syndrome..$^{15}$ Most studies performed in recent years have used definitions published by the World Health Organization (WHO) ${ }^{2}$ and by the National Cholesterol Education Program/Adult Treatment Panel III (NCEP/ATP III), ${ }^{3}$ which was later revised. ${ }^{4} \mathrm{~A}$ similar definition was adopted in 2005 by the International Diabetes Federation (IDF). ${ }^{5}$ The most often used definitions are presented in Table 1.,2,3,23

Two years later, the first consensus-based definition of MS in children was published ${ }^{8}$ (Table 2), whether it unifies the field remains to be seen. Namely, in pediatric studies as many as 40 different definitions of MS have been applied. ${ }^{24}$ Some of them are presented in Table $3 ;^{11,25-27}$ for the whole list of studies some good reviews are available. ${ }^{24,28}$

Most researchers have used adapted definitions of MS in adults, especially NCEP/ATP III $^{3}$ and the World Health Organization, ${ }^{2}$ with components of MS adjusted according to age and percentile values. ${ }^{25-27,29}$ Difficulties in defining the MS in children arise from their different growth patterns, from the influence of hormonal changes in puberty on insulin resistance and lipid profiles, and from ethnic differences. ${ }^{14}$ Additionally, there has been no universal agreement about which level of particular component to use for the criteria. Instead, values above the $85^{\text {th }}, 90^{\text {th }}, 95^{\text {th }}, 97^{\text {th }}$ and even $75^{\text {th }}$
Correspondence: Natasa Marcun Varda, Department of Pediatrics, University Medical Centre Maribor, Ljubljanska 5, 2000 Maribor, Slovenia. E-mail: natasa.marcunvarda@amis.net

Key words: metabolic syndrome, cardiovascular diseases, obesity, child, prevention, treatment.

Received for publication: 30 January 2009.

Revision received: 5 May 2009.

Accepted for publication: 15 May 2009.

This work is licensed under a Creative Commons Attribution 3.0 License (by-nc 3.0)

(C) Copyright N. Marcun Varda, A. Gregoric 2009 Pediatric Reviews 2009;1:e1

doi:10.4081/pr.2009.e1

percentile for age and gender have been used (Table 3). For this reason, comparison between studies is difficult. Recently, first studies using pediatric IDF definition have been published. ${ }^{30,31}$

In addition to five components of the clinical definition of MS, there are numerous associated findings, including procoagulant and proinflammatory states ${ }^{15,32}$ (Table 4).

\section{Prevalence of metabolic syndrome}

The prevalence of MS in adults, according to the NCEP/ATP III, was found to be around 15\% in Europe ${ }^{33}$ and $24 \%$ in the United States, ${ }^{34}$ respectively, most probably due to obesity and unhealthy lifestyles in the latter. Many studies showed that MS prevalence is highly dependent on the definition used. ${ }^{35-37}$ Prevalence results of studies, comparing WHO with the NCEP/ATP III definition, were mostly similar, ${ }^{36}$ whereas in most studies using the IDF definition, the prevalence was higher, ${ }^{36}$ reaching even $43.4 \%{ }^{37}$ The situation is similar in the pediatric population, where the increasing prevalence of obesity, ${ }^{13}$ as well as obesity-related diseases, such as hypertension, ${ }^{10}$ type 2 diabetes ${ }^{38}$ and CV diseases, ${ }^{39}$ was established. For American children, the prevalence of MS was found to be $9.2 \%$ in the period from 1988 to 1994 and $12.7 \%$ from 1999 to 2000 . During this period, the percentage of children with a body mass index above the $85^{\text {th }}$ percentile increased from 25.9 to $30.5 \% .{ }^{11}$ In most other studies, the prevalence of MS in the general pediatric population was lower for both American and other pediatric patients, ${ }^{28,40}$ dependent not only on definition but also on the percentile cut-offs used. ${ }^{41}$ In the study of Goodman et al., prevalence, using ATP III and WHO criteria, was found to be $4.2 \%$ and $8.4 \%$, respectively. ${ }^{27}$ In studies using pediatric IDF definition, prevalence for American adolescents was found to be $4.5 \%{ }^{30}$ and $2.4 \%$ for Finnish adolescents. ${ }^{31}$ In obese children, the prevalence is $30 \%{ }^{25}$ and reaches $50 \%$ in extremely obese children. ${ }^{26}$ 
Table 1. Definition of metabolic syndrome according to the World Health Organization (WHO), ${ }^{2}$ the National Cholesterol Education Program/Adult Treatment Panel III (NCEP/ATP III), ${ }^{3}$ the European Group for the study of Insulin Resistance (EGIR) ${ }^{23}$ and the International Diabetes Federation (IDF). ${ }^{5}$

\begin{tabular}{|c|c|c|c|c|}
\hline Component of metabolic syndrome & WHO & EGIR & NCEP/ATP III & IDF \\
\hline Insulin resistance (IR) & + & + & & \\
\hline $\begin{array}{l}\text { Fasting blood glucose } \\
\text { (or impaired glucose tolerance)(mmol/L) }\end{array}$ & $\begin{array}{l}\geq 6.1 \\
\text { ( } \geq 7.8 \text { or type } 2 \text { diabetes })\end{array}$ & $\geq 6.1$ & $\geq 6.1$ & $\geq 5.6$ \\
\hline $\begin{array}{l}\text { Waist circumference }(\mathrm{cm}) \\
\text { or waist / hip ratio (WHR) }\end{array}$ & $\begin{array}{l}\text { Men }>0.9 \\
\text { Women }>0.85 \text { (WHR) }\end{array}$ & $\begin{array}{l}\text { Men } \geq 94 \\
\text { Women } \geq 80\end{array}$ & $\begin{array}{l}\text { Men }>102 \\
\text { Women }>88\end{array}$ & $\begin{array}{l}\text { Men } 94 \\
\text { Women } \geq 80 \text {, } \\
\text { ethnically specific values }\end{array}$ \\
\hline Body mass index $\left(\mathrm{kg} / \mathrm{m}^{2}\right)$ & $>30$ & & & \\
\hline Triglycerides (mmol/L) & $\geq 1.7$ & $>2.0$ & $\geq 1.7$ & $\geq 1.7$ or specific therapy \\
\hline HDL- cholesterol (mmol/L) & $\begin{array}{l}\text { Men }<0.9 \\
\text { Women }<1.0\end{array}$ & $<1.0$ & $\begin{array}{l}\text { Men }<1.04 \\
\text { Women }<1.29\end{array}$ & $\begin{array}{l}\text { Men }<1.02 \\
\text { Women }<1.29 \text { or specific therapy }\end{array}$ \\
\hline Blood pressure (mmHg) & $\geq 140 / 90$ & $\geq 140 / 90$ & $\geq 130 / 85$ & $\geq 130$ / 85 or specific therapy \\
\hline Number of components & $\begin{array}{l}\text { IR or impaired fasting glucose } \\
\text { or glucose intolerance }+ \\
\geq 2 \text { others or microalbuminuria }\end{array}$ & IR $+\geq 2$ others & $\geq 3$ & Central obesity +2 others \\
\hline
\end{tabular}

Table 2. Definition of pediatric metabolic syndrome according to the International Diabetes Federation.

\begin{tabular}{ll} 
Age (Years) & Criteria for the metabolic syndrome \\
$<10$ & Obesity (waist circumference $>90^{\text {th }}$ percentile), \\
& metabolic syndrome as entity is not diagnosed \\
& Waist circumference $>90^{\text {th }}$ percentile or adult \\
& cut-off if lower \\
& Triglycerides $\geq 1.7 \mathrm{mmol} / \mathrm{L}$ \\
& HDL-cholesterol $<1.03 \mathrm{mmol} / \mathrm{L}$ \\
& Glucose $\geq 5.6 \mathrm{mmol} / \mathrm{L}$ or type 2 diabetes mellitus \\
& Sistolic blood pressure $\geq 130$ or diastolic blood \\
& pressure $\geq 85 \mathrm{mmHg}$ \\
\hline & Adult criteria \\
\hline
\end{tabular}

For the diagnosis, central obesity and 2 of 4 other components must be present.

Table 3. Comparison of the metabolic syndrome criteria used in some pediatric studies.

\begin{tabular}{|c|c|c|c|c|}
\hline $\begin{array}{l}\text { Metabolic syndrome } \\
\text { components }\end{array}$ & Cook et al. ${ }^{25}$ & de Ferranti et al. "I & Weiss et al..$^{26}$ & Goodman et al. ${ }^{2 \pi}$ \\
\hline $\begin{array}{l}\text { Fasting glucose } \\
(\mathrm{mmol} / \mathrm{L})\end{array}$ & $\geq 6.1$ & $\geq 6.1$ & $\begin{array}{l}\text { Impaired glucose } \\
\text { tolerance }\end{array}$ & $\begin{array}{l}\geq 6.1 \text {, insulin } \\
\text { resistance } \\
>75^{\text {th }} \text { percentile(IR) }\end{array}$ \\
\hline $\begin{array}{l}\text { Waist circumference or } \\
\text { body mass index (BMI) }\end{array}$ & $\geq 90^{\text {th }}$ percentile & $>75^{\mathrm{th}}$ percentile & $\begin{array}{l}\text { BMI z score > } 2 \\
\text { for age and sex }\end{array}$ & $\begin{array}{l}\text { males } 102 \mathrm{~cm} \text { females } 88 \mathrm{~cm} \\
\text { or BMI } \geq 95^{\dagger} \text { percentile }\end{array}$ \\
\hline $\begin{array}{l}\text { Triglycerides } \\
\text { (mmol/ or percentiles) }\end{array}$ & $\geq 1.2$ & $\geq 1.1$ & $\begin{array}{l}>95^{\text {मh }} \\
\text { percentile }\end{array}$ & $\geq 1.7$ \\
\hline $\begin{array}{l}\text { HDL-cholesterol } \\
\text { (mmo/L or percentiles) }\end{array}$ & $\begin{array}{l}\leq 1.04 \\
\leq\end{array}$ & $\begin{array}{l}<1.2(<1.3 \text { for } \\
\text { boys } 15-19 \text { years })\end{array}$ & $\begin{array}{l}<5^{\pitchfork} \\
\text { percentile }\end{array}$ & $\begin{array}{l}\text { males } \leq 0.9 \\
\text { females } \leq 1.01 \leq\end{array}$ \\
\hline Blood pressure & $\geq 90^{\mathrm{th}}$ percentile & $\geq 90^{\text {th }}$ percentile & $\begin{array}{l}\geq 95^{\text {th }} \\
\text { percentile }\end{array}$ & $\geq 130 / 85 \mathrm{~mm} \mathrm{Hg}$ \\
\hline Number of components & $\geq 3$ & $\geq 3$ & $\geq 3$ & IR or type 2 diabetes +2 others \\
\hline
\end{tabular}

Like many other countries, we have no national prevalence data on MS in our country. This is an important task for the future. Nevertheless, we have been able to conduct a study on prevalence of MS in our children with

\section{Pathophysiology of metabolic syndrome}

In contrast to adults, pathophysiological mechanisms for MS in children have been poorly investigated. The central role of insulin resistance has been proposed, although other mechanisms are also involved..$^{15}$ Resistance to the actions of insulin on carbohydrate and lipid metabolism can explain all components of MS, and in part, atherogenesis ${ }^{43}$ (Table 5).

There are also an increasing number of studies investigating novel biological actions of insulin, which have shown that hyperinsulinemia itself contributes to atherogenecity. ${ }^{43}$ The important role of free fatty acids in insulin resistance through specific actions that block insulin signal transduction should also be stressed. In addition, they contribute to induction of oxidative stress, inflammation and subnormal vascular reactivity. ${ }^{44}$ According to the inflammatory hypothesis, the proinflammatory state in obesity influences insulin resistance and MS. ${ }^{43}$ Both free fatty acids and inflammatory cytokines are involved in insulin resistance, the development of a prothrombotic and proinflammatory state, and in atherogenesis.

\section{Obesity and metabolic syndrome}

The mechanism of the influence of obesity on CV diseases and type 2 diabetes is presented in Figure $1 .^{14}$ Obesity is closely related to insulin resistance, the most common abnormality seen in obesity. In obesity, enlarged adipocytes produce more proinflammatory cytokines, such as tumor necrosis factor- $\alpha$ and interleukin-6, and less anti-inflammatory peptides, such as adiponectin. ${ }^{45}$ Childhood obesity which progresses into adulthood is associated with a higher morbidity and mortality than adult-onset obesity. ${ }^{46}$ In addition to genetic factors, obesity is the most important risk factor 
Table 4. Components of metabolic syndrome.

\begin{tabular}{ll}
\hline 1. & Insulin resistance* \\
\hline 2. & Hyperinsulinemia* \\
\hline 3. & Obesity: visceral (central), but also generalized obesity* \\
4. & Dyslipidemia: high triglycerides, low HDL, small dense LDL* \\
\hline 5. & Adipocyte dysfunction \\
6. & Impaired glucose tolerance or type 2 diabetes mellitus* \\
\hline 7. & Fatty liver (non-alcoholic steatohepatosis, steatohepatitis) \\
8. & Essential hypertension: increased systolic and diastolic blood pressure* \\
\hline 9. & Endothelial dysfunction \\
10. & Renal dysfunction (micro- or macroalbuminuria) \\
\hline 11. & Polycystic ovary syndrome \\
12. & Inflammation: increased CRP and other inflammatory markers \\
\hline 13. & Hypercoagulability (increased fibrinogen and plasminogen activator inhibitor-1) \\
14. & Atherosclerosis leading to increased cardiovascular morbidity and mortality* \\
\hline
\end{tabular}

*Most widely incorporated into the definition of metabolic syndrome..

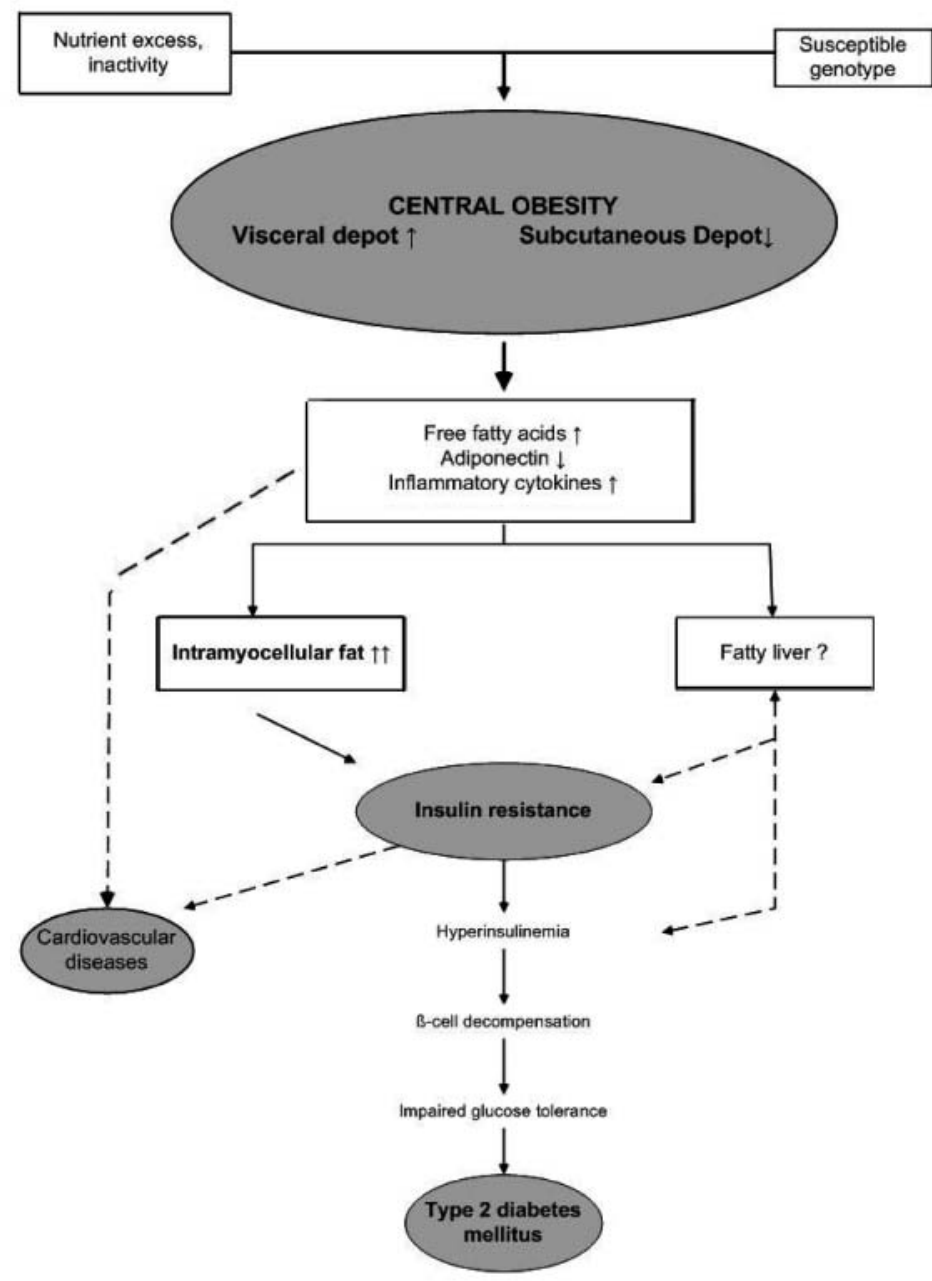

Figure 1. Mechanism of the influence of obesity on cardiovascular diseases and type 2 diabetes.

for MS according to all the above-mentioned mechanisms. $^{26}$

Abdominal obesity can be easy assessed using the simple measurement of waist cir- cumference (WC) which is known to correlate more strongly with visceral adipose tissue than body mass index, another measure of obesity, in both adults and children, and is a strong pre- dictor of $\mathrm{CV}$ risk factors. ${ }^{47,48} \mathrm{WC}$ percentile nomograms in children have only recently become available for some ethnic groups ${ }^{49}$ but are not available for all. In addition, there is no internationally accepted classification of age specific cut-off values. To overcome these limitations, an index of the ratio between waist and height has recently been proposed for clinical use, as it does not require percentile tables. Several studies have shown that this index is a good predictor of metabolic and CV risks. $^{48,50}$

\section{Dyslipidemia and metabolic syndrome}

Atherogenic dyslipidemia, namely elevated triglycerides, low high-density lipoprotein (HDL)-cholesterol and small dense low-density lipoprotein (LDL), is present in MS. Atherogenic dyslipidemia is included in all published definitions of MS. ${ }^{2,34,5,23}$ Studies have shown that the risk of dyslipidemia in predicting $\mathrm{CV}$ risk is similar to that of high LDL-cholesterol. ${ }^{51}$ Both excessive fat deposition and genetic predisposition are involved in the development of abnormal adipose tissue. When insulin resistance blocks the inhibitory effect of insulin on adipocyte lipolysis, adipocytes increase the release of free fatty acids, which are transported to the liver. The liver incorporates free fatty acids into triglycerides, which are assembled into very low-density lipoproteins. Very lowdensity lipoproteins exchange triglycerides for cholesteryl esters from LDL and HDL. Most of the cholesteryl esters return to the liver in remnant particles after very low-density lipoprotein triglycerides have been hydrolyzed by lipoprotein lipase. This is regarded as a favorable effect. However, some of the cholesteryl esters may end up in the arterial wall; the proatherogenic effect. When enriched with triglycerides, both HDL and LDL are subject to lipolysis by hepatic lipase, resulting in smaller particles. Lipolyzed HDL particles, which exhibit an anti-atherogenic effect by participating in reverse cholesterol transport and by antioxidant mechanisms, are cleared more rapidly. Small dense LDL particles, formed after lipolysis of triglyceride-rich LDL, are atherogenic, probably due to increased penetration of the arterial intima and decreased antioxidant capacity. ${ }^{15}$

\section{Hypertension and metabolic syndrome}

Hypertension is one of the important components of MS. The relationship between hypertension and the MS is complex, most probably because of its multifactorial nature. An association between both hypertension and body weight and hypertension and insulin resistance has been found in children. ${ }^{52}$

Angiotensin and other neurohormonal mediators of hypertension have effects on 
Table 5. Metabolic effects of insulin and consequences of insulin resistance.

Normal insulin action Insulin-resistance state

\begin{tabular}{|c|c|c|}
\hline Carbohydrates & $\begin{array}{l}\downarrow \text { Hepatic glucose production } \\
\uparrow \text { Glucose utilization } \\
\uparrow \text { Glycogenesis }\end{array}$ & $\begin{array}{l}\text { Hyperglycemia } \\
\text { Hyperinsulinemia }\end{array}$ \\
\hline Lipids & $\begin{array}{l}\downarrow \text { Lipolysis } \\
\downarrow \text { Free fatty acids and glycerol } \\
\uparrow \text { Lipogenesis } \\
\uparrow \text { HDL } \\
\downarrow \text { Triglycerides }\end{array}$ & $\begin{array}{l}\text { 个 Lipolysis } \\
\uparrow \text { Free fatty acids and glycerol } \\
\uparrow \text { Hepatic triglyceride and apoB synthesis } \\
\downarrow \text { HDL } \\
\text { Hypertriglyceridemia } \\
\uparrow \text { Small dense LDL }\end{array}$ \\
\hline Proteins & $\begin{array}{l}\downarrow \text { Gluconeogenesis } \\
\downarrow \text { Amino acids } \\
\uparrow \text { Protein synthesis }\end{array}$ & $\begin{array}{l}\uparrow \text { Gluconeogenesis } \\
\uparrow \text { Protein catabolism } \\
\downarrow \text { Protein synthesis }\end{array}$ \\
\hline Purines & $\begin{array}{l}\uparrow \text { Uric acid clearance } \\
\downarrow \text { Uric acid formation }\end{array}$ & Hyperuricemia \\
\hline
\end{tabular}

intrarenal hemodynamics and renal electrolyte handling, thus participating in blood pressure control. Increased adipocyte mass leads to increased production of angiotensinogen, providing a potential mechanism for increased blood pressure. ${ }^{53}$ Adipocytes also produce angiotensin-converting enzyme and cathepsins, which effect local angiotensin conversion and catabolism, and other substances of the renin-angiotensin system. ${ }^{54,55}$ Angiotensin itself promotes the growth of adipocytes. ${ }^{54}$ Free fatty acids have been shown to increase angiotensinogen production and promote oxidative stress in endothelial cells, an effect that is amplified by angiotensin. ${ }^{53}$ Hyperinsulinemia may have a direct influence on elevated blood pressure by its activity on the sympathetic nervous system ${ }^{56}$ and by sodium reabsorption in the kidney. ${ }^{57}$ In addition, it indirectly influences mechanisms important for vasodilation through nitric oxide release and production of other vasodilators. ${ }^{58}$ In one study of children with hypertension, MF was found in $17 \%$ of study subjects. ${ }^{42}$ A recent extensive assessment of various metabolic parameters in a group of children found to have primary hypertension demonstrated an association between left ventricular hypertrophy and MS in hypertensive children. ${ }^{59}$

\section{Proinflammatory and prothrombo- tic state and metabolic syndrome}

Adipose tissue is not only a reservoir for energy but serves as an active secretory organ, releasing peptides and cytokines into the circulation. ${ }^{14}$ In obesity, the dysregulated production of adipocytokines has been found to participate in the development of metabolic and CV diseases. $^{60}$ Obesity is associated with subclinical chronic inflammation. ${ }^{61}$ In obese children, an elevated level of CRP has been found ${ }^{62}$ and its correlation with other MS components demonstrated. ${ }^{63}$ Values of CRP and interleukin- 6 have been found to correlate with the degree of obesity, ${ }^{26}$ insulin resistance and systolic blood pres- sure ${ }^{61}$ Adiponectin levels, reduced in obese children, correlate negatively with body mass index, levels of triglycerides and free fatty acids and positively with insulin sensitivity ${ }^{45}$ The prothrombotic state in MS arises from changes in the coagulation and fibrinolytic systems, in thrombocytes and in vascular endothelial cells. ${ }^{32}$ The most extensively studied factors associated with atherogenesis are fibrinogen and plasminogen activator inhibitor- $1{ }^{64}$ The latter is also associated with type 2 diabetes. ${ }^{65}$

\section{Genetics and metabolic syndrome}

Most of the components of MS, such as hypertension and hypertriglyceridemia, as well as associated abnormalities, are influenced by genetic factors. Considering only the genetics of insulin resistance, it can be said in summary, that the clustering of insulin resistance in some families has been well known for a long time. ${ }^{66}$ Twin studies have shown that the influence of genetic factors is in the range of $47-66 \%{ }^{67}$ Mutations in genes for insulin receptors, ${ }^{68}$ defects in glucose transporter molecule ${ }^{69}$ and other genetic abnormalities (e.g. generalized lipodystrophy) are associated with insulin resistance. ${ }^{70}$ These genetic abnormalities are important for a better understanding of insulin resistance and for research into better treatment options; however, they can only explain a minor part of the genetic variability of insulin resistance. It should be stressed that several molecular pathways in energy homeostasis, lipid metabolism, the insulin receptor signaling pathway, cytokines, hormone-binding proteins and other protease regulators are responsible for the development of insulin resistance. ${ }^{70}$

\section{Some other important components and metabolic syndrome}

In recent years, an increasing number of factors and diseases have been connected with MS and even proposed as its components. Some of them are presented in Table $4 .^{15}$
Non-alcoholic fatty liver disease (NAFLD), characterized by the accumulation of large droplets of triglycerides within hepatocytes in the absence of chronic alcohol consumption, is the most common cause of pediatric liver disease. ${ }^{71}$ It has been associated with obesity and insulin resistance. ${ }^{72}$ In addition, studies in children have shown that it is strongly associated with multiple $\mathrm{CV}$ risk factors and MS, independently of body mass index, hyperinsulinemia ${ }^{73}$ and the amount of visceral adipose tissue, indicating that fat accumulation in the liver may play a more important role than obesity itself in determining the metabolic risk. ${ }^{74}$ Moreover, fatty liver may prove to be a mediator of MS. ${ }^{73}$ It is also associated with type 2 diabetes and advanced liver disease ${ }^{75}$ as well as with carotid atherosclerosis. ${ }^{76}$ The most important therapeutic measure is increasing insulin sensitivity by an attempt to lose weight. Several pharmacolological agents have also been used, mostly metformin. ${ }^{77}$

A number of studies have also reported strong association between concentrations of uric acid and the MS or its components in both adults ${ }^{78}$ and children ${ }^{79}$ although uric acid is not part of any definition of the MS. Uric acid has also been associated with primary hypertension and a key role in its pathogenesis proposed. ${ }^{80}$ Moreover, it has been shown that allopurinol lowers uric acid and blood pressure in young hypertensives. ${ }^{80}$ In obese children, the association with carotid atherosclerosis has been demonstrated. ${ }^{81}$

Endothelial dysfunction is thought to be one of the earliest events in the development of atherosclerosis and has also been associated with MS in some studies. ${ }^{82,83}$ Recent insights into vascular biology have enabled us to understand the molecular mechanisms underlying endothelial dysfunction. ${ }^{84}$ In studies, vascular endothelial function has often been evaluated using measurement of brachial artery flowmediated dilation and detection of selected molecules, released by dysfunctional endothelium..$^{85}$ Numerous studies have been performed in obese children, and functional and structural vascular changes identified. ${ }^{85-87}$ Abdominal adipose tissue accumulation has been associated with $\mathrm{CV}$ risk factors and with the elastic properties of the abdominal aorta in obese children. $^{88}$

\section{Management of children with metabolic syndrome}

Follow-up of adult patients with MS has shown that, in every patient with a single CV risk factor, all the other risk factors must be sought and individually treated. ${ }^{7}$ At present, there are no unified consensus-based definition guidelines for the management of children with MS, an important and urgent task for the future,$^{89}$ although some preventive guidelines in cardiovascular health in childhood do 
exist. ${ }^{90}$ The American Diabetes Association has published guidelines for detection of children with type 2 diabetes. Testing is recommended for children with high-risk factors for type 2 diabetes, namely obesity, family history, highrisk ethnic groups and clinical signs associated with insulin resistance. ${ }^{91}$ We are of the opinion that the same guidelines should be applied to both adults and children. All children with essential hypertension are managed accordingly in our department. ${ }^{92}$ The same guidelines have been proposed by the American Heart Association. ${ }^{89}$

A thorough family history and history of previous diseases and present difficulties is obtained for each child. The importance of family history, which is an independent risk factor $^{93}$ and which is associated with changes in risk variables from childhood to adulthood, must be stressed. ${ }^{94,95}$ Examination of the patient, anthropometrical measurements, blood pressure measurement and laboratory investigations are performed. Normal and cutoff values of metabolic parameters for different age groups in some populations are still problematic. For normal blood pressure values we use European measurements. ${ }^{96,97}$ Body mass index is used to establish obesity. ${ }^{98}$ Normal values for waist circumference, which is a measure of abdominal obesity and directly associated with insulin resistance, have been published for some populations. ${ }^{49,99}$ Recently, a linear correlation between these two parameters has been found in children, so both can be used. ${ }^{100}$ For dyslipidemia, most researchers and physicians use their own normal values. ${ }^{101}$ For glucose metabolism, in addition to fasting glucose, fasting insulin is also determined and the homeostasis model assessment of insulin resistance (HOMA-IR) calculated. ${ }^{102}$ Sometimes an oral glucose tolerance test is also performed. Measurement of fasting insulin correlates with the standard euglycemic clamp method for assessment of insulin resistance, which is expensive and time consuming. ${ }^{103}$ The oral glucose tolerance test is a good indicator of insulin resistance. ${ }^{104}$

The importance of novel CV risk factors in children has been investigated in some studies. ${ }^{105}$ Although the positive predictive value of some of the parameters has already been demonstrated, their definitive place in the management of children with the MS has yet to be defined. Studies have investigated the role of CRP, ${ }^{26,61-63,105,106}$ interleukin- $6,{ }^{26,61}$ adiponectine ${ }^{45,105,107,108}$ plasminogen activator inhibitor- $1,{ }^{65}$ leptin, ${ }^{105,109}$ homocysteine ${ }^{110}$ and others factors.

\section{Treatment of children with metabolic syndrome}

MS and related diseases are an important public health problem. Therefore, for optimal detection and management of patients, a glob- al program is needed. ${ }^{111}$ Preventive measures must be instigated in childhood, that is, healthy lifestyle education, with emphasis on healthy nutrition and physical activity. The best prevention is prevention of the development of obesity. Measurements of body weight, body height and blood pressure are recommended from the age of three years. ${ }^{111}$ With such management for each individual, CV risk factors will be ascertained at an early stage, the total CV risk determined and treatment started when necessary. When one or more CV risk factors are demonstrated in a child, treatment and follow-up are started. The basic treatment always consists of non-pharmacological measures, namely, lifestyle modification with regular physical activity, healthy nutrition, and maintenance of the recommended body weight. This is a healthy lifestyle, applicable to everybody. For healthy nutrition, the daily energy intake has to be reduced and adjusted to body weight. The daily diet must contain all essential components of the important foodstuff groups in five daily portions. The main aims of proper nutrition are appropriate calorie intake, optimal nutrition for health maintenance and normal growth, and maintenance of healthy nutrition habits throughout life. Fat and protein intake must be adapted to the age of the child (fat: for children from 1-3 years old $30-40 \%$ of daily calories, for older children 25-30\%; protein: from 1-3 years old 5-20\%, for older children 10 $30 \%)$. Carbohydrates should be included in the range of $45-65 \%$. Saturated fat must be restricted $(<10 \%)$, as well as cholesterol $(<300$ $\mathrm{mg} /$ day), salt ( $<6 \mathrm{~g} /$ day) and simple sugars. Food must contain enough fiber (age of the child $+5 \mathrm{~g} /$ day $){ }^{90}$

Lack of physical activity is one of the important causes of the MS. Therefore, regular exercise is vital. For improvement in insulin sensitivity, at least 30-60 minutes of aerobic exercise daily is recommended. ${ }^{90,112}$ In addition, exercises for strength, which diminish insulin resistance, enlarge muscle mass and reduce visceral adipose tissue, are advised. ${ }^{113}$ Regular physical activity can improve insulin sensitivity by $40 \% .{ }^{114}$ It has been demonstrated that eight weeks of aerobic exercises improve strength, values of HDL cholesterol and endothelial function. ${ }^{115}$ Additionally, sedentary activities must to be reduced to less than two hours per day. ${ }^{116}$ Physical activity and diet undoubtedly play important roles in MS. However, research with precise measurements of exercise, diet and metabolic outcomes is needed.

It has been shown that tobacco exposure independently influences the development of MS. Therefore, prohibition of smoking is essential. ${ }^{117}$

Both parents and children must be counseled and educated. The whole family must change their lifestyle habits, because CV risk factors cluster in families as a result of unhealthy lifestyle and genetic factors. Regular follow-up, education, support and stimulation are necessary.

Management and treatment of children with MS and its components also include various intervention programs. School-based programs are a notable example, highlighting the importance of developing a favorable environment that promotes balanced eating behaviors and extra-curricular physical activity. ${ }^{118}$ Studies also support family-based programs. ${ }^{119}$

We should also stress the importance of psychological aspects of MS in children. It seems that MS and depressive symptoms are linked in both directions. Namely, findings suggest that psychological characteristics, especially depression, hostility and anger, may increase the risk for the MS. ${ }^{120}$ On the other hand, it has been shown that MS in childhood predicts depressive syndromes in adulthood. ${ }^{121}$ Therefore, psychosocial prevention and treatment interventions have to be included in the management of these patients.

If non-pharmacological measures are unsuccessful, drug treatment should be considered.

Pharmacological treatment of obesity is limited. Sibutramin is effective, but its usage is associated with side effects. ${ }^{122}$ Orlistat treatment is approved for treatment of obese adolescents. ${ }^{123}$ In several studies, the efficacy of metformin was demonstrated in children with MS, but its definitive role must be evaluated in further studies, in particular its long-term efficacy and safety. ${ }^{124,125}$ Surgical treatment is limited to patients with a body mass index above $40 \mathrm{~kg} / \mathrm{m}^{2}$ and with associated diseases such as obstructive apnea, type 2 diabetes and pseudotumor cerebri. ${ }^{126}$

Treatment of type 2 diabetes in adolescents is the same as in adults. ${ }^{127,128}$ In one study, $90 \%$ of patients with the MS and type 2 diabetes were treated with medications for blood sugar control, 40\% with antihypertensive medications, and $10 \%$ with medication for fat reduction. ${ }^{128}$

Guidelines for pharmacological treatment of hypertension include symptomatic hypertension, hypertensive target organ damage, stage 2 hypertension, stage 1 hypertension not improving after non-pharmacological measures, and hypertension with associated type 2 diabetes. ${ }^{129,130}$ As first-line treatment, inhibitors of the renin-angiotensin system (angiotensinconverting enzyme inhibitors, angiotensin receptor blockers) or calcium channel blockers are recommended. The former are the firstline treatment in patients with associated type 2 diabetes or renal disease, especially if proteinuria is present. ${ }^{131,132}$

Treatment of dyslipidemia is started with a low fat diet, especially with low saturated fat 
and cholesterol, a high fiber intake, addition of phytosterols, body weight control and regular physical activity. If these measures are unsuccessful, treatment with medications, e.g. statins is indicated, if there are no contraindications. ${ }^{133}$ Well controlled studies of the efficacy, short-term safety and benefit of the statins have been conducted in children ${ }^{134}$ and recently guidelines for treatment have been proposed. ${ }^{135,136}$ However, for optimal treatment of children with the MS, future studies, especially prospective studies, are needed. ${ }^{137}$

\section{Conclusion}

$\mathrm{CV}$ risk factors, comprising the MS, do appear in childhood, eventually progress in adulthood, and are associated with higher CV morbidity in adults. In all children with a single CV risk factor, all other known risk factors should be determined. Each child with a single detected CV risk factor must be treated individually, initially with non-pharmacological treatment interventions. Children with several CV risk factors are at higher risk, necessitating meticulous follow-up and treatment. Children with MS components in the lower normal range are at a lower $\mathrm{CV}$ risk, indicating the need for healthy lifestyle promotion in early childhood. It should be stressed that primary care doctors and nurses play an important role in $\mathrm{CV}$ prevention and detection of individuals with a higher CV risk. The MS must not be just a new pediatric syndrome, but it should represent a challenge for better prevention strategies.

\section{References}

1. Reaven GM. Banting lecture 1988. Role of insulin resistance in human disease. Diabetes 1988;37:1595-607.

2. Alberti KG, Zimmet PZ. Definition, diagnosis and classification of diabetes mellitus and its complications. Part I: diagnosis and classification of diabetes mellitus provisional report of a WHO consultation. Diabet Med 1998;15:539-53.

3. Executive Summary of the Third Report of the National Cholesterol Education Program (NCEP) Expert Panel on Detection, Evaluation, and Treatment of High Blood Cholesterol in Adults (Adult Treatment Panel III). JAMA 2001;285:248697.

4. Grundy SM, Cleeman JI, Daniels SR, et al. Diagnosis and management of the metabolic syndrome. An American Heart Association/National Heart, Lung, and Blood Institute scientific statement.
Circulation 2005;112:1-18.

5. Alberti KG, Zimmet P, Shaw J. IDF Epidemiology Task Force Consensus Group. The metabolic syndrome - a new worldwide definition. Lancet 2005;366: 1059-62.

6. Reaven GM. The metabolic syndrome: is the diagnosis necessary? Am J Clin Nutr 2006;83:1237-47.

7. Kahn R, Buse J, Ferrannini E, Stern M. The metabolic syndrome: time for critical appraisal. Joint statement from the American Diabetes Association and the European Association for the Study of Diabetes. Diabetes Care 2005;28:2289-304.

8. Zimmet P, Alberti KG, Kaufman F, et al. The metabolic syndrome in children and adolescents - an IDF consensus report. Pediatr Diabetes 2007;8:299-306.

9. Smoak CG, Burke GL, Webber LS, et al. Relation of obesity to clustering of cardiovascular disease risk factors in children and young adults: the Bogalusa Heart Study. Am J Epidemiol 1987;125:364-72.

10. Sorof JM, Lai D, Turner J, et al. Overweight, ethnicity, and the prevalence of hypertension in school-aged children. Pediatrics 2004;113:475-82.

11. de Ferranti SD, Gauvreau K, Ludwig DS, et al. Inflammation and changes in metabolic syndrome abnormalities in US adolescents: findings from the 1988-1994 and 1999-2000 National Health and Nutrition Examination Surveys. Clin Chem 2006;52: 1325-30.

12. Sorof J, Daniels S. Obesity hypertension in children; a problem of epidemic proportions. Hypertension 2002;40:441-7.

13. Hedley AA, Ogden CL, Johnson CL, et al. Prevalence of overweight and obesity among US children, adolescents, and adults, 1999-2002. JAMA 2004;291:2847-50.

14. Weiss R, Caprio S. The metabolic consequences of childhood obesity. Best Pract Res Clin Endocrinol Metab 2005;19:405-19.

15. Miranda PJ, DeFronzo RA, Califf RM, Guyton JR. Metabolic syndrome: definition, pathophysiology, and mechanisms. Am Heart J 2005;149:33-45.

16. Chen W, Srinivasan SR, Li XJ, Berenson GS. Clustering of long-term trends in metabolic syndrome variables from childhood to adulthood in Blacks and Whites: the Bogalusa Heart Study. Am J Epidemiol 2007;166:527-33.

17. Nguyen QM, Srinivasan SR, Xu JH, et al. Changes in risk variables of metabolic syndrome since childhood in pre-diabetic and type 2 diabetic subjects: the Bogalusa Heart Study. Diabetes Care 2008;31:20449.

18. Srinivasan SR, Meyers L, Berenson GS. Changes in metabolic syndrome variables since childhood in prehypertensive and hypertensive subjects: the Bogalusa Heart Study. Hypertension 2006;48:33-9.

19. Hanson RL, Imperatore G, Bennett PH, Knowler WC. Components of the "metabolic syndrome" and incidence of type diabetes 2. Diabetes 2002;51:3120-7.

20. Lakka HM, Laaksonen DE, Lakka TA, et al. The metabolic syndrome and total and cardiovascular disease mortality in middleaged men. JAMA 2002;288:2709-16.

21. Stamler J, Stamler R, Neaton JD, et al. Low-risk factor profile and long-term cardiovascular and noncardiovascular mortality and life expectancy: findings for 5 large cohorts of young adult and middle-aged men and women. JAMA 1999;282:2012-8.

22. Chen W, Srinivasan SR, Li S, et al. Metabolic syndrome variables at low levels in childhood are beneficially associated with adulthood cardiovascular risk: the Bogalusa Heart Study. Diabetes Care 2005; 28:138-43.

23. Balkau B, Charles MA. Comment on the provisional report from the WHO consultation. European Group for the Study of Insulin Resistance. Diabet Med 1999;16: 442-3.

24. Ford ES, Li C. Defining the metabolic syndrome in children and adolescents: will the real definition please stand up? J Pediatr 2008;152:160-4.

25. Cook S, Weitzman M, Auinger $\mathrm{P}$, et al. Prevalence of a metabolic syndrome phenotype in adolescents: findings from the third National Health and Nutrition Examination Survey, 1988-1994. Arch Pediatr Adolesc Med 2003;157:821-7.

26. Weiss R, Dziura J, Burgert TS, et al. Obesity and the metabolic syndrome in children and adolescents. N Engl J Med 2004;350:2362-74.

27. Goodman E, Daniels SR, Morrison JA, et al. Contrasting prevalence of and demographic disparities in the World Health Organisation and National Cholesterol Education Program Adult Treatment Panel III definitions of metabolic syndrome among adolescents. J Pediatr 2004;145: 445-51.

28. Steinberger J, Daniels SR, Eckel RH, et al. Progress and challenges in metabolic syndrome in children and adolescents: a scientific statement from the American Heart Association Atherosclerosis, Hypertension, and Obesity in the Young Committee of the Council on Cardiovascular Disease in the Young; Council on Cardiovascular Nursing; and Council on Nutrition, Physical Activity, and Metabolism. Circulation 2009;119:628-47.

29. Jolliffe CJ, Janssen I. Development of agespecific adolescent metabolic syndrome criteria that are linked to the Adult Treatment Panel III and International 
Diabetes Federation criteria. J Am Coll Cardiol 2007; 49: 891-8.

30. Ford ES, Li C, Zhao G, et al. Prevalence of the metabolic syndrome among U.S. adolescents using the definition from the International Diabetes Federation. Diabetes Care 2008;31:587-9.

31. Pirkola J, Tammelin T, Bloigu A, et al. Prevalence of metabolic syndrome at age 16 using the International Diabetes Federation paediatric definition. Arch Dis Child 2008;93:945-51.

32. Palomo I, Alarcon M, Moore-Carrasco R, Argiles JM. Hemostasis alterations in metabolic syndrome. Int $\mathrm{J}$ Mol Med 2006;18:969-74.

33. Miccoli R, Bianchi C, Odoguardi L, et al. Prevalence of the metabolic syndrome among Italian adults according to ATP III definition. Nutr Metab Cardiovasc Dis 2005;15:250-4.

34. Ford ES, Giles WH, Dietz WH. Prevalence of the metabolic syndrome among US adults: findings from the third National Health and Nutrition Examination Survey. JAMA 2002;287:356-9.

35. Churilla JR, Fitzhugh EC, Thompson DL. The metabolic syndrome: how definition impacts the prevalence and risk in US adults: 1999-2004 NHANES. Metab Syndr Relat Disord 2007;5:331-42.

36. Santos AC, Barros H. Impact of metabolic syndrome definitions on prevalence estimates: a study in a Portuguese community. Diab Vasc Dis Res 2007;4:320-7.

37. Athyros VG, Ganotakis ES, Elisaf M, Mikhailidis DP. The prevalence of the metabolic syndrome using the National Cholesterol Educational Program and International Diabetes Federation definitions. Curr Med Res Opin 2005;21:1157-9.

38. Rosenbloom AL, Joe JR, Young RS, Winter WE. Emerging epidemic of type 2 diabetes in youth. Diabetes Care 1999;22:345-54.

39. Lawlor DA, Leon DA. Association of body mass index and obesity measured in early childhood with risk of coronary heart disease and stroke in middle age: findings from Aberdeen children of the 1950s prospective cohort study. Circulation 2005;111:1891-6.

40. Agirbasli M, Cakir S, Ozme S, Ciliv G. Metabolic syndrome in Turkish children and adolescents. Metabolism 2006;55: 1002-6.

41. Chi CH, Wang Y, Wilson DW, Robinson TN. Metabolic syndrome in preadolescent girls: comparing proposed definitions in two population-based samples. J Pediatr 2006;148:788-92.

42. Munoz S. Blood pressure studies in paediatric populations: metabolic syndrome in hypertensive children and adolescents. J Hum Hypertens 2000;14[Suppl 1]:S10-5.
43. Dandona P, Aljada A, Chaudhuri A, et al. Metabolic syndrome. A comprehensive perspective based on interactions between obesity, diabetes, and inflammation. Circulation 2005;111:1448-54.

44. Triypathy D, Mohanty P, Dhindsa S, et al. Elevation of free fatty acids induces inflammation and impairs vascular reactivity in healthy subjects. Diabetes 2003; 52:2882-7.

45. Weiss R, Dufour S, Groszmann A, et al. Low adiponectin levels in adolescent obesity: a marker of increased intramyocellular lipid accumulation. J Clin Endocrinol Metab 2003;88:2014-8.

46. Deitz W. Health consequences of obesity in youth. Childhood predictors of adult disease. Pediatrics 1998;101:518-26.

47. Pouliot MC, Despres JP, Lemieux S, et al. Waist circumference and abdominal sagittal diameter: best simple anthropometric indexes of abdominal visceral adipose tissue accumulation and related cardiovascular risk in men and women. Am J Cardiol 1994;73:460-8.

48. Savva SC, Tornaritis M, Savva ME, et al. Waist circumference and waist-to-height ratio are better predictors of cardiovascular disease risk factors in children than body mass index. Int $\mathrm{J}$ Obes Relat Metab Disord 2000;24:1453-8.

49. Fernandez JR, Redden DT, Pietrobelli A, Allison DB. Waist circumference percentiles in nationally representative samples of African-American, EuropeanAmerican, and Mexican-American children and adolescents. J Pediatr 2004; 145:439-44.

50. Maffeis C, Banzato C, Talamini G. Obesity Study Group of the Italian Society of Pediatric Endocrinology and Diabetology. Waist-to-height ratio, a useful index to identify high metabolic risk in overweight children. J Pediatr 2008;152:207-13.

51. Jeppesen J, Hein HO, Suadicani P, Gyntelberg F. Relation of high TG-low HDL cholesterol and LDL cholesterol to the incidence of ischemic heart disease. An 8-year follow up in the Copenhagen Male Study. Arterioscler Thromb Vasc Biol 1997;17: 1114-20.

52. Sinaiko A, Steinberger J, Moran A, et al. Relation of insulin resistance to blood pressure in childhood. J Hypertens 2002; 20:509-17.

53. Egan BM, Green EL, Goodfriend TL. Insulin resistance and cardiovascular disease. Am J Hypertens 2001;14:116S-25S.

54. Engeli S, Schling P, Gorzelniak K, et al. The adipose-tissue renin-angiotensin-aldosterone system: role in the metabolic syndrome? Int J Biochem Cell Biol 2003; 35:807-25.

55. Goossens GH, Blaak EE, van Baak MA.
Possible involvement of the adipose tissue renin-angiotensin system in the pathophysiology of obesity and obesity-related disorders. Obes Rev 2003;4:43-55.

56. Esler M, Rumantir M, Kaye D, Lambert G. The sympathetic neurobiology of essential hypertension: disparate influences of obesity, stress, and noradrenaline transporter dysfunction? Am J Hypertens 2001;14:139S $-46 \mathrm{~S}$.

57. Ferrannini E, Natali A. Insulin resistance and hypertension: connections with sodium metabolism. Am J Kidney Dis 1993;21 Suppl:37-42.

58. Sowers JR, Frohlich ED. Insulin and insulin resistance: impact on blood pressure and cardiovascular disease. Med Clin N Am 2004;88:63-82.

59. Litwin M, Sladowska J, Antoniewicz J, et al. Metabolic abnormalities, insulin resistance, and metabolic syndrome in children with primary hypertension. Am J Hypertens 2007;20:875-82.

60. Yudkin JS, Kumari M, Humphries SE, Mohamed-Ali V. Inflammation, obesity, stress and coronary heart disease: is interleukin-6 the link? Atherosclerosis 2000; 148:209-14.

61. Festa A, D'Agostino JrR, Howard G, et al. Chronic subclinical inflammation as part of the insulin resistance syndrome: the Insulin Resistance Atherosclerosis Study (IRAS). Circulation 2000;102:42-7.

62. Ford ES, Galuska DA, Gillespie C, et al. Creactive protein and body mass index in children: findings from the Third National Health and Nutrition Examination Survey, 1988-1994. J Pediatr 2001;138:486-92.

63. Cook DG, Mendall MA, Whincup PH, et al. C-reactive protein concentration in children: relationship to adiposity and other cardiovascular risk factors. Atherosclerosis 2000;149:139-50.

64. Juhan-Vague I, Alessi MC, Mavri A, Morange PE. Plasminogen activator inhibitor-1, inflammation, obesity, insulin resistance and vascular risk. J Thromb Haemost 2003;1575-79.

65. Festa A, D'Agostino R Jr, Tracy RP, Haffner SM. Elevated levels of acute-phase proteins and plasminogen activator inhibitor1 predict the development of type 2 diabetes: the Insulin Resistance Atherosclerosis Study. Diabetes 2002;51: 1131-7.

66. Martin BC, Warram JH, Rosner B, et al. Familiy clustering of insulin sensitivity. Diabetes 1992;41:850-4.

67. Stern MP. Strategies and prospects for finding insulin resistance genes. J Clin Invest 2000;106:323-7.

68. Taylor SI. Lilly lecture: molecular mechanisms of insulin resistance. Lessons from patients with mutations in the insulinreceptor gene. Diabetes 1992;41:1473-90 
69. Stuart CA, Wen G, Williamson ME, et al. Altered GLUT1 and GLUT3 gene expression and subcellular redistribution of GLUT4: protein in muscle from patients with acanthosis nigricans and severe insulin resistance. Metabolism 2001;50: 771-7.

70. Ten S, MacLaren N. Insulin resistance syndrome in children. J Clin Endocrinol Metab 2004;89:2526-39.

71. Schwimmer JB, Deutsch R, Kahen T, et al. Prevalence of fatty liver in children and adolescents. Pediatrics 2006;118:1388-93.

72. Pagano G, Pacini G, Musso G, et al. Nonalcoholic steatohepatitis, insulin resistance, and metabolic syndrome: further evidence for an etiologic association. Hepatology 2002;35:367-72.

73. Schwimmer JB, Pardee PE, Lavine JE, et al. Cardiovascular risk factors and the metabolic syndrome in pediatric nonalcoholic fatty liver disease. Circulation 2008; 118:277-83.

74. Seppala-Lindroos A, Vehkavaara S, Hakkinen AM, et al. Fat accumulation in the liver is associated with defects in insulin suppression of glucose production and serum free fatty acids independent of obesity in normal men. J Clin Endocrinol Metab 2002;87:3023-8.

75. Younossi ZM, Gramlich T, Matteoni CA, et al. Nonalcoholic fatty liver disease in patients with type 2 diabetes. Clin Gastroenterol Hepatol 2004;2:262-5.

76. Pacifico L, Cantisani V, Ricci P, et al. Nonalcoholic fatty liver disease and carotid atherosclerosis in children. Pediatr Res 2008;63:423-7.

77. Nobili V, Manco M, Ciampalini P, et al. Metformin use in children with nonalcoholic fatty liver disease: an open-label, 24month, observational pilot study. Clin Ther 2008;30:1168-76.

78. Lee J, Sparrow D, Vokonas PS, et al. Uric acid and coronary heart disease risk: evidence for a role of uric acid in the obesityinsulin resistance syndrome. The Normative Aging Study. Am J Epidemiol 1995;142: 288-94.

79. Ford ES, Li C, Cook S, Choi HK. Serum concentrations of uric acid and the metabolic syndrome among US children and adolescents. Circulation 2007;115:2526-32.

80. Feig DI, Nakagawa T, Karumanchi A, et al. Hypothesis: uric acid, nephron number, and the pathogenesis of essential hypertension. Kidney Int 2004;66:281-7.

81. Pacifico L, Cantisani V, Anania C, et al. Serum uric acid and its association with metabolic syndrome and carotid atherosclerosis in obese children. Eur J Endocrinol 2009;160:45-52.

82. Melikian N, Chowienczyk P, MacCarthy PA, et al. Determinants of endothelial function in asymptomatic subjects with and without the metabolic syndrome. Atherosclerosis 2008;197:375-82.

83. Ghiadoni L, Penno G, Giannarelli C, et al. Metabolic syndrome and vascular alterations in normotensive subjects at risk of diabetes mellitus. Hypertension 2008;51: 440-5.

84. Nacci C, Tarquinio M, Montagnani M. Molecular and clinical aspects of endothelial dysfunction in diabetes. Intern Emerg Med 2009;4:107-16.

85. Glowinska-Olszewska B, Tolwinska J, Urban M. Relationship between endothelial dysfunction, carotid artery intima media thickness and circulating markers of vascular inflammation in obese hypertensive children and adolescents. J Pediatr Endocrinol Metab 2007;20:1125-36.

86. Mori Y. Flow-mediated dilatation in obese children. Clin Pediatr Endocrinol 2003;12: 43-8.

87. Mimoun E, Aggoun Y, Pousset M, et al. Association of arterial stiffness and endothelial dysfunction with metabolic syndrome in obese children. $\mathrm{J}$ Pediatr 2008;153:65-70.

88. Polat TB, Urganci N, Caliskan KC, Akyildiz B. Correlation of abdominal fat accumulation and stiffness of the abdominal aorta in obese children. $\mathrm{J}$ Pediatr Endocrinol Metab 2008;21:1031-40.

89. Steinberger J, Daniels SR. Obesity, insulin, resistance, diabetes and cardiovascular risk in children: an American Heart Association Scientific Statement from the atherosclerosis, hypertension, and obesity in the Young Committee (Council on Cardiovascular Disease in the Young) and Diabetes Committee (Council on Nutrition, Physical Activity, and Metabolism). Circulation 2003;107:144853.

90. Daniels RS, Arnett DK, Eckel RK, et al. Overweight in children and adolescents: pathophysiology, consequences, prevention, and treatment. Circulation 2005;111:1999-2012.

91. American Diabetes Association (ADA). Consensus statement - Type 2 diabetes in children and adolescents. Diabetes Care 2000;22:381-7.

92. Varda NM, Gregoric A. A diagnostic approach for the child with hypertension. Pediatr Nephrol 2005;20:499-506.

93. Myers RH, Kiely DK, Cupples LA, Kannel WB. Parental history is an independent risk factor for coronary artery disease: the Framingham Study. Am Heart J 1990;120: 963-9.

94. Youssef AA, Valdez R, Elasabany A, Srinivasan SR, Berenson GS. Time-course of adiposity and fasting insulin from childhood to young adulthood in offspring of parents with coronary artery disease: the Bogalusa Heart Study. Ann Epidemiol 2002;12:553-9.

95. Srinivasan SR, Frontini MG, Berenson GS, Bogalusa Heart Study. Longitudinal changes in risk variables of insulin resistance syndrome from childhood to young adulthood in offspring of parents with type 2 diabetes: the Bogalusa Heart Study. Metabolism 2003;52:443-50.

96. De Man SA, Andre JL, Bachman H, et al. Blood pressure in children: pooled findings of six European studies. J Hypertens 1991;9:109-14.

97. Soergl M, Kirschstein M, Busch C, et al. Oscillometric twenty-four-hour ambulatory blood pressure values in healthy children and adolescents: a multicenter trial including 1141 subjects. J Pediatr 1997;130: 17884.

98. Kromeyer-Hauschild K, Wabitsch M, Kunze D, et al. Perzentile für den Bodymass-Index für das Kindes- und Jugendalter unter Heranziehung verschiedener deutscher Stichproben. Monatsschr Kinderheilkd 2001;149:807-18.

99. Eisenmann JC. Waist circumference percentiles for 7- to 15-year-old Australian children. Acta Paediatr 2005;94:1182-5.

100.Morimoto A, Nishimura R, Kanda A, et al. Waist circumference estimation from BMI in Japanese children. Diabetes Res Clin Pract 2007;75:96-8.

101.Csabi G, Török K, Jeges S, Molnar D. Presence of metabolic cardiovascular syndrome in obese children. Eur $\mathrm{J}$ Pediatr 2000;159:91-4.

102.Matthews DR, Hosker JP, Rudenski AS, et al. Homeostasis model assessment: insulin resistance and ß-cell function from fasting plasma glucose and insulin concentrations in man. Diabetologia 1985;28: 412-9.

103.Granberry MC, Fonseca VA. Insulin resistance syndrome: options for treatment. South Med J 1999;92:2-14.

104.Yeckel CW, Weiss R, Dziura J, et al. Validation of insulin sensitivity indices from oral glucose tolerance test parameters in obese children and adolescents. J Clin Endocrinol Metab 2004;89:1096-101.

105. Retnakaran R, Zinman B, Connelly PW, et al. Nontraditional cardiovascular risk factors in pediatric metabolic syndrome. $\mathrm{J}$ Pediatr 2006;148:176-82.

106.Patel DA, Srinivasan SR, Xu JH, et al. Distribution and metabolic syndrome correlates of plasma C-reactive protein in biracial (black-white) younger adults: the Bogalusa Heart Study. Metabolism 2006; 55:699-705.

107.Gilardini L, McTernan GP, Girola A, et al. Adiponectin is a candidate marker of metabolic syndrome in obese children and 
adolescents. Atherosclerosis 2006;189:4017.

108.0gawa Y, Kikuchi T, Nagasaki K, et al. Usefulness of serum adiponectin level as a diagnostic marker of metabolic syndrome in obese Japanese children. Hypertens Res 2005;28:51-7.

109.Nishina M, Kikuchi T, Yamazaki H, et al. Relationship among systolic blood pressure, serum insulin and leptin, and visceral fat accumulation in obese children. Hypertens Res 2003;26:281-8.

110.Martos R, Valle M, Morales R, et al. Hyperhomocysteinemia correlates with insulin resistance and low-grade systemic inflammation in obese prepubertal children. Metab Clin Exp 2005;55:72-7.

111.Bestermann W, Houston MC, Basile J, et al. Addressing the global cardiovascular risk of hypertension, dyslipidemia, diabetes mellitus, and the metabolic syndrome in the southeastern United States, part II: treatment recommendations for management of the global cardiovascular risk of hypertension, dyslipidemia, diabetes mellitus, and the metabolic syndrome. Am J Med Sci 2005;3296:292-305.

112.American Diabetes Association (ADA). ADA consensus development conference on insulin resistance. Diabetes Care 1998; 21:310-14.

113.Schmidt-Trucksass A. The metabolic syndrome and sports. MMW Fortschr Med 2006;148:30-2.

114.Hoffman RP, Stumbo PJ, Janz KF. Altered insulin resistance is associated with increased dietary weight loss in obese children. 1995;44:17-22.

115. Kelly AS, Wetzsteon RJ, Kaiser DR, et al. Inflammation, insulin, and endothelial function in overweight children and adolescents: the role of exercise. J Pediat 2004;145:731-6.

116.Epstein LH, Paluch RA, Gordi CC, Dorn J. Decreasing sedentary behaviours in treating pediatric obesity. Arch Pediatr Adolesc Med 2000;154:220-6.

117.Weitzman M, Cook S, Auinger P, et al.
Tobacco smoke exposure is associated with metabolic syndrome in adolescents. Circulation 2006;112:862-9.

118.Angelopoulos PD, Milionis HJ, Grammatikaki E, et al. Changes in BMI and blood pressure after a school based intervention: The CHILDREN study. Eur J Public Health 2009;19:319-25.

119. Nowicka P, Flodmark CE. Family in pediatric obesity management: a literature review. Int J Pediatr Obes 2008;3Suppl 1: 44-50.

120.Goldbacher EM, Matthews KA. Are psychological characteristics related to risk of the metabolic syndrome? A review of the literature. Ann Behav Med 2007;34:240-52.

121.Pulkki-Råback L, Elovainio M, Kivimäki M, et al. Depressive symptoms and the metabolic syndrome in childhood and adulthood: a prospective cohort study. Health Psychol 2009;28:108-16.

122.Berkowitz RI, Wadden TA, Tershakovec AM, Cronquist JL. Behaviour therapy and sibutramine for the treatment of adolescents obesity: a randomized controlled trial. JAMA 2003;289:1805-12.

123.McDuffie JR, Calis KA, Uwaifo GI, et al. Three-month tolerability of orlistat in adolescents with obesity-related comorbid conditions. Obes Res 2002;10:642-50.

124.Srinivasan S, Ambler GR, Baur LA, et al. Randomized, controlled trial of metformin for obesity and insulin resistance in children and adolescents: improvement in body composition and fasting insulin. $\mathrm{J}$ Clin Endocrinol Metab 2006;91:2074-80.

125.Freemark M. Pharmacologic approaches to the prevention of type 2 diabetes in high risk pediatric patients. J Clin Endocrinol Metab 2003;88:3-13.

126.Inge TH, Krebs NF, Garcia BF, et al. Bariatric surgery for severly overweight adolescents: concerns and recommendations. Pediatrics 2004;114:217-23.

127.Sanders BH, Lubsch LM, West DS. Prevalence and treatment of metabolic syndrome in adolescents with type 2 diabetes. Ann Pharmacother 2006;40:1517-21.
128.Urakami T. How should we treat type 2 diabetes in youth? Pediatr Endocrinol 2005; 3:33-9.

129.Luma GB, Spiotta RT. Hypertension in children and adolescents. Am Fam Physician 2006;73:1558-68.

130.Puri M, Flynn JT. Management of hypertension in children and adolescents with the metabolic syndrome. J Cardiometab Syndr 2006;1:259-68.

131.Woroniecki RP, Flynn JT. How are hypertensive children evaluated and managed? A survey of North American pediatric nephrologists. Pediatr Nephrol 2005;20: 791-7.

132.National High Blood Pressure Education Program Working Group on High Blood Pressure in Children and Adolescents. The Fourth Report on the Diagnosis, Evaluation, and Treatment of High Blood Pressure in Children and Adolescents. Pediatrics 2004;144 Suppl:555-76.

133. Holmes KW, Kwiterovich POJr. Treatment of dyslipidemia in children and adolescents. Curr Cardiol Rep 2005;7:445-56.

134.Wiegman A, Hutten BA, de Groot E, Rodenburg, et al. Efficacy and safety of statin therapy in children with familial hypercholesterolemia: a randomized controlled trial. JAMA 2004;292:331-7.

135.Daniels SR, Greer FR, Committee in Nutrition. Lipid screening and cardiovascular health in childhood. Pediatrics 2008;122:198-208.

136.Mc Crindle BW, Urbina EM, Dennison BA, et al. Drug therapy of high-risk lipid abnormalities in children and adolescents: a scientific statement from American Heart Association Atherosclerosis, Hypertension, and Obesity in Youth Committee. Council of Cardiovascular Disease in the Young, with the Council on Cardiovscular Nursing. Circulation 2007;115:1948-67.

137.Sarti C, Gallagher J. The metabolic syndrome: prevalence, CHD risk, and treatment. J Diabetes Complications 2006;20: 121-32. 
